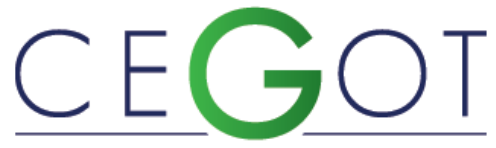

Centro de Estudos de Geografia e Ordenamento do Território
Medeiros, CLAUDiA

Laboratório de Estudos das Dinâmicas Territoriais na Amazônia LEDTAM

R. Cel. José Porfírio - São Sebastiao, Altamira - PA, 68371-000, Brazil claudia_smedeiros@outlook.com

\section{HERRERA, JOSE}

Universidade Federal do Pará (UFPA)

Instituto de Tecnologia - R. Augusto Corrêa, 01 - Guamá, Belém - PA, 66075-110, Brazil

herrera@ufpa.br

\title{
A Usina Hidrelétrica Belo Monte e o direito à cidade na Amazônia: 0 caso da Lagoa do Independente I em Altamira, Pará (Brasil)
}

The hidrolectric power plant of Belo Monte and the right to the city in Amazonia: The caso of the Independente Lake in Altamira, Pará (Brasil)

Referência: Medeiros, C.; Herrera, J. (2020). A Usina Hidrelétrica Belo Monte e o direito à cidade na Amazônia: O caso da Lagoa do Independente I em Altamira, Pará (Brasil). Revista de Geografia e Ordenamento do Território (GOT), n. 19 (Junho). Centro de Estudos de Geografia e Ordenamento do Território, p. 158-185, dx.doi.org/10.17127/got/2020.19.007

\section{RESUMO}

A implantação de hidrelétricas na Amazônia promove dinâmicas socioespaciais e desigualdades socioeconômicas e ambientais. A instalação e construção da UHE Belo Monte foi essencial para a requalificação urbana na cidade de Altamira e a reestruturação de seus espaços. Neste contexto e na perspectiva de contribuir para a compreensão das transformações urbanas, através da análise bibliográfica, documental e de entrevistas com moradores da Lagoa do Independente I, os esforços desta pesquisa foram direcionados para a reflexão a propósito do aumento populacional e sua correlação com a instalação da usina. A preocupação foi orientada sobretudo para a degradação socioambiental a as condições de vida da população, tomando como conceito chave o de direito à cidade.

Palavras-chave: Dinâmicas socioespaciais; desigualdades socioeconômicas; direito à cidade.

\section{ABSTRACT}

The implementation of hydroelectric power plants in the Amazon region is a dynamic sociospatial process producing socioeconomic and environmental inequalities. The installation and construction of the UHE Belo Monte was determinant for urban requalification in the city of Altamira and the restructuring of its spaces. In view of this context, in the perspective of contributing to urban studies, through bibliographic, documentary analysis and interviews with residents of Lagoa do Independente I, the efforts of this research were directed at reflecting the population increase of the area and its correlation with the 
industrial plant. The focus is the socio-environmental degradation having as central preoccupation the "right to the city" principle.

Keywords: Socio-spatial dynamics; socioeconomic inequalities; right to the city.

\section{Introdução}

Salvo aqueles que vivem de modo sustentável e em relação harmoniosa com a natureza, pode considerar-se que a sociedade no modelo estabelecido na Amazônia sempre buscou suprir as demandas do capital. Tal formato moldou aspectos da economia e sociedade que, regra geral, tal como noutras partes do mundo, procuram servir essencialmente necessidades externas, sejam elas de caráter nacional ou internacional e se preocupam pouco com as demandas e interesses socioeconômicos locais; ao contrário, a exploração da nova fronteira erigida na lógica da natureza como mercadoria considera a realidade e vivências dos povos da Amazônia, como indígenas e ribeirinhos, "transformando a região em área de livre acesso ao capital mundial" (Herrera, 2016, p.2).

Esse processo, ao longo dos anos, contou com "...o uso extremo da força e o poder do Estado na criação de condições gerais de produção propícias à forma de crescimento adotada" (Santos, 2007, p. 15), o que reverberou na manutenção de cidades e sociedades com contradições espaciais e sociais extremas que possuem como base de formatação não apenas a formação histórica e geográfica, mas também a inserção de grandes projetos, que, por vezes, alteram drasticamente as características socioespaciais preexistentes. Esses fatores, aliados ao histórico nacional de grandes concentrações de renda e terras, acentua fortemente um quadro de desigualdade social em que boa parte da população não possui acesso a direitos sociais previsto na lei, como o acesso a "educação, a saúde, a alimentação, o trabalho, a moradia, o transporte, o lazer, a segurança, a previdência social, a proteção à maternidade e à infância, a assistência aos desamparados" (Constituição Federal, 2016, p. 18).

Nesse contexto, Altamira, um dos 144 municípios paraenses, com uma população estimada em 2019 de 114.595 pessoas (IBGE, 2020), ou seja, 15.519 a mais em relação ao último levantamento feito pelo Instituto Brasileiro de Geografia e Estatística (IBGE), no censo de 
$2010^{1}, 99.075$ pessoas, compõe a Amazônia brasileira e é um dos muitos exemplos de cidades da região Norte que sofrem implicações espaciais decorrentes do avanço das novas demandas do capital durante todo o seu processo formativo "desde a prevalência da economia gomífera na bacia do Rio Xingu" (Miranda Neto, 2016, p. 91), passando pela densificação populacional, ocasionada principalmente pela ação direta dos programas de integração nacional impostos pelo regime militar a partir da década de 1970, até à contemporaneidade da implantação da Usina de Belo Monte ${ }^{2}$.

Os efeitos dessas novas fronteiras do capital são diversos e muito importantes para a reestruturação do espaço, com grandes projetos na Amazônia a marginalizar os já marginalizados, na expressão de Herrera e Santana (2016, p. 255), como é o caso do que sucede na Lagoa do Independente I, que aqui se estuda.

A Lagoa do Independente I é uma ocupação irregular localizada no interior do bairro Independente I, em Altamira (PA), que, segundo pesquisas de campo do Laboratório de Estudos das Dinâmicas territoriais na Amazônia (LEDTAM) de 2017 apontam, teve a sua gênese em meados da década de 1980 (informação não condiz com os estudos feitos pela Semas em 2016) ${ }^{3}$. Sendo certo que a Lagoa apresenta desde a sua formação problemas socioambientais, somente a partir dos efeitos decorrentes da hidrelétrica, dentre eles um novo panorama de exploração do solo e consequente valorização imobiliária, com processos de especulação, se aprofunda a exclusão/marginalização de uma parcela da população já em condições de vulnerabilidade social e econômica. A área da Lagoa passa então a ter uma ocupação intensa, do que resulta um notável aumento populacional, num processo que não tem o devido acompanhamento do setor público nem do privado.

\footnotetext{
${ }^{1}$ O último censo realizado no Brasil foi no ano de 2010. Nele, foram visitados 67,6 milhões de domicílios nos 5.565 municípios brasileiros (IBGE, 2010).

${ }^{2}$ A Usina Hidrelétrica Belo Monte é uma obra do Programa de Aceleração do Crescimento (PAC) com investimentos superiores a 25,8 bilhões de reais e com capacidade instalada de 11.233,1 (média de 4.571 $\mathrm{MW}$ ), que quando finalizada se tornará a terceira maior usina do mundo (Ministério do Panejamento, 2011).

${ }^{3}$ Os estudos analisados durante a elaboração deste trabalho apontam divergências sobre a década de início do processo formativo da lagoa (1980 ou 1990). Em pesquisas de campo realizadas em 2017 e 2018 pelo Laboratório de Estudos das Dinâmicas territoriais na Amazônia (LEDTAM), vinculado a Universidade Federal do Pará - UFPA, os moradores relatam o início, período de instalação de suas moradias no local ainda na década de 1980, o que contrapõe aos dados recolhidos em relatório técnico da Secretaria de Estado de Meio Ambiente e Sustentabilidade - SEMAS (2016) que informa que a área da Lagoa do Independente I tem sua ocupação datada apenas nos anos de 1990.
} 
Os esforços da pesquisa que subsidiou este artigo foram direcionados para a compreensão dos fatores desencadeados pela instalação da UHE Belo Monte que levaram ao afluxo populacional no interior da Lagoa do Independente I e à análise da exclusão do direito à cidade dos seus residentes, verificando como um grupo de cidadãos ficaram excluídos de direitos constituídos em lei, considerando-se esta porção do bairro Independente I, conhecida popularmente como Lagoa do Independente I, no quadro do desenvolvimento urbano da cidade de Altamira, uma vez que este espaço não está desconexo do que ocorre a sua volta.

A pesquisa iniciou-se com a análise bibliográfica e documental de obras relevantes que versam sobre o espaço urbano, o urbano na Amazônia, cidadania, direito à cidade e urbanização, designadamente obras de carácter teórico que subsidiam a reflexão e compreensão do processo formativo da cidade de Altamira e dos diferentes processos que ocorreram até a constituição da Lagoa do Independente I e os efeitos oriundos da UHE Belo Monte. Trabalhados sob a perspetiva dialética, por se entender que no espaço urbano o fenômeno do adensamento populacional, para ser compreendido, necessita do diálogo entre o objeto de estudo, a "lagoa", e seu contexto, o espaço urbano de Altamira, bem como de seu passado, sua gênese e sua configuração socioespacial, em um movimento contínuo de criação e recriação do espaço e da sociedade.

Foram realizadas entrevistas com os que habitam o interior da lagoa, para aproximar a teoria, com a vivência e as percepções dos sujeitos, que produzem e reproduzem o espaço, ao mesmo tempo em que são produzidos e transformados por ele. Esta escolha se deu fundamentalmente pelo interesse em investigar o modus vivendi de uma população específica, condicionada a viver em condições precárias e insalubres, em consequência direta da falta de serviços básicos de saneamento, saúde e cidadania, sem acesso a água potável, coleta de lixo domiciliar, escola, posto de saúde e áreas de lazer, entre outros.

Tratar a cidadania como um componente da investigação geográfica auxilia a refletir e a compreender o espaço geográfico como uma instância social, um conjunto de relações que ocorreram e ocorrem em determinado espaço e que agem como fator social e não apenas como reflexo da sociedade, futuro.

(...) O espaço por suas características e por seu funcionamento, pelo que ele oferece a alguns e recusa a outros, pela seleção de localização feita entre as 
atividades e entre os homens, é o resultado de uma práxis coletiva que reproduz as relações sociais, (...) o espaço evolui pelo movimento da sociedade total (SANTOS, 1978, p.171).

Numa linha possibilista "não é absurdo afirmar que somos mais ou menos cidadãos de acordo com o espaço em que estamos inseridos" (PIÑON DE OLIVEIRA, 2012, p. 178). Ancorados nessa ideia, usa-se as concepções elaboradas por Milton Santos, nas obras "A natureza do espaço: técnica e tempo, razão e emoção" (2009) e o "O espaço do cidadão" (2007), nas quais o autor apresenta pontos de grande relevância para esta pesquisa ao expor sob a óptica do espaço, a cidadania.

A cidadania não é, portanto, simplesmente uma representação dos indivíduos dentro do Estado Nacional, é, sem dúvida, um fenômeno muito mais complexo que incide no quadro da dinâmica territorial cotidiana da sociedade. (...) As discussões sobre cidadania e democracia não podem portanto ignorar mais que estas noções possuem uma dimensão ontológica e fundadora.

Tendo em vista esta dimensão fundadora entre estes dois termos, a ideia de cidadania pode nos ser útil para compreender a dinâmica de fenômenos e disputas sócio-territoriais que ocorrem no mundo atual, valorizando o aspecto de disputa por espaço que é simultaneamente condição e meio de exercício desta cidadania (GOMES, 1997, p. 50).

Esta interpretação aproximada da leitura da obra de Henri Lefebvre, "O direito à cidade" (2001), "formulado como o direito à vida urbana, transformada e renovada" (p. 117), ajuda à compreensão das modificações que ocorrem no espaço urbano amazônico, o que é ter direito à cidade e como esse direito é suprimido pela ação hegemônica do capital, materializado, neste texto, com o ocorrido em Altamira mediante a implantação da UHE Belo Monte.

Outra obra importante para a interpretação feita aqui é a obra de 2014 "Cidades rebeldes: do direito à cidade à revolução urbana", de David Harvey, por aproximar o percebido nesta pesquisa com processos que ocorrem em grandes centros, mas que segundo o autor podem ocorrer também, sempre que "certas características ambientais urbanas são propícias à eclosão de protestos insurgentes" (Harvey, 2014, p. 212). Além disso, contribui com a reflexão no que tange a ação contra-hegemónica, como fica evidente na seguinte passagem do texto:

Se a urbanização é tao crucial para a história da acumulação do capital e seus inumeráveis aliados devem mobilizar-se sem descanso para revolucionar periodicamente a vida urbana, então uma luta de classes de algum tipo, não 
importa se explicitamente reconhecida como tal, está inevitavelmente envolvida (HARVEY, p.209, 2014).

Nestes termos, busca-se aprofundar o entendimento sobre o capitalismo, seus enigmas e possíveis ações no urbano, para a reflexão a propósito do papel e importância da organização social e seus movimentos, representados na área da Lagoa pelos moradores e integrantes do Movimento dos Atingidos por Barragens (MAB), que se constitui na defesa de direitos e de resistência anticapitalista para a obtenção de direitos.

\section{Segregação urbana, cidadania e a luta pelo direito à cidade}

As relações sociais e a (re) produção espacial estão na base da exclusão social, uma segregação urbana engendrada principalmente pelo conflito decorrente da produção espacial ao longo dos tempos e da apropriação privada em uma sociedade constituída em classes, o que é especialmente evidente quando a desigualdade é maior, tal como ocorre no Brasil, como elucida Carlos (2016),

(...) a segregação - característica fundamental da produção do espaço urbano contemporâneo -, em seus fundamentos, é o negativo da cidade e da vida urbana. Seu pressuposto é a compreensão da produção do espaço urbano como condição, meio e produto da reprodução social - portanto um produto histórico e de conteúdo social. Submetida à lógica da acumulação, essa produção realiza a acumulação capitalista cujos objetivos se elevam e se impõem ao uso social da cidade. Este processo realiza a desigualdade na qual se assenta a sociedade de classes, apoiada na existência da propriedade privada da riqueza que cria acessos diferenciados dos cidadãos à metrópole, em sua totalidade, a partir da aquisição da moradia. A produção do espaço funda-se, assim, na contradição entre a produção social da cidade e sua apropriação privada. A existência da propriedade privada da riqueza apoiada numa sociedade de classes e a constituição do espaço como valor de troca geram a luta pelo "direto à cidade" (Carlos, 2016, p.95).

O próprio valor do homem depende de sua localização no espaço (Santos, 2007, p. 108), escolha determinada, muitas vezes, pelo fator econômico. É evidente que existe uma gama de hipóteses que podem elucidar a formação de bolsões de pobreza e segregação, onde a cidadania e o direito à cidade são negados. A gestão da cidade é, sem dúvida, uma destas variáveis, pois, da forma como é gerida, onde existe uma centralidade do poder e não há uma participação eficiente da população nos direcionamentos que possam saciar seus anseios, torna-se uma cidade do capital e não do cidadão. Este é um processo que marca as 
grandes cidades do Brasil e o modelo que se reproduz nas cidades amazônicas, como é o caso de Altamira, no estado do Pará.

Embora, as políticas públicas sejam orientadas para atender aos interesses da população, a forma como são implementadas ou por sua ineficácia, acabam por beneficiar prioritariamente corporações que comandam as dinâmicas do mercado, mesmo quando adequam estas ao local em que estão sendo inseridas. Tais políticas, não se aplicam a todos os cidadãos, na realidade:

O que está em questão é o fato de que o processo de produção do urbano ocorre, hoje, a partir de um processo de universalização do trabalho e das trocas, em função das estratégias gerais no nível da formação econômica da sociedade capitalista. Trata-se de um espaço mundial dividido, diferenciado, hierarquizado e antagônico, onde a metrópole tem, estrategicamente, o papel de comando na articulação das parcelas desse espaço, na medida em que concentra o poder financeiro, político e econômico. (Carlos, p. 98, 2008)

Ressalta-se que, embora Carlos (2008) no fragmento supracitado esteja se referindo a (re) produção do espaço em uma metrópole, considera-se que há a reprodução deste modelo explica o que ocorre em Altamira e no objeto de estudo delimitado em pesquisa, a Lagoa do Independente I, haja vista que, as ações decorrentes do empreendimento hidrelétrico, a UHE Belo Monte, reforçam o controle sobre o poder financeiro, político e econômico em atores externos, reduzindo ou até excluindo uma parcela da população, ali residente, das beneficies da vida na cidade e segregados de direitos constituídos em lei, da cidadania.

Em geral, alguns autores consideram mesmo que, em boa parte do Mundo, nas sociedades contemporâneas, a cidadania está mais atrelada a direitos políticos como o voto, do que aos direitos cívicos e sociais, e é marcada pelos conflitos de classe. Pode-se afirmar também que a própria "cidadania" não foi internalizada pelos sujeitos, uma vez que o cidadão está muito mais ancorado na ideia de ser um usuário, consumidor da cidade (Santos, 2007), do que um agente pensante, crítico e produtor do espaço em que está inserido.

Pensar o espaço geográfico sob a perspectiva do direito à cidade pode permitir a reflexão e compreensão do espaço como uma instância social e também fazê-lo partir duma lógica

\footnotetext{
${ }^{4}$ Com relação ao conceito de cidadania [...] uma rápida incursão histórica nos mostra que, no século XIX, com a emergência do Estado-Nação em toda a Europa, este conceito adquiriu um importante elemento: a qualidade de membro. Pelo simples fato de ser membro de um Estado-nação, todos os habitantes ascendiam ao status de cidadão, o direito político de participar da construção da sociedade, se efetivaria somente depois do voto. Até um passado bem recente - início do século XX - este direito será reservado a alguns [...] (Santos apud T. Haguette, 2012, p. 21)
} 
espaço/sociedade que é moldada de acordo com os interesses e demandas do capital, neste caso consolidadas pela implantação da UHE Belo Monte, indutora de efeitos de segregação socioespacial.

Deste modo, o espaço urbano de Altamira, ao longo de sua formação histórica, é produzido e reproduzido sob a égide do valor de troca, formato que se sobrepõe ao valor de uso social, quadro acirrado a cada nova demanda. A noção de produção do espaço, sob o ponto de vista de Santos $(1978,2007,2009)$ e Lefebvre (2001), possibilita reconstruir o movimento do espaço geográfico através de sua materialidade histórica, um caminho que permite pensar o espaço como uma mercadoria, "posta na prateleira", na totalidade da produção social capitalista (Carlos, 2008).

Nas cidades, esse valor de troca entra em conflito com os direitos sociais constituídos em lei, o que no caso brasileiro é assegurado principalmente pela Constituição Federal (CF) promulgada em 1988 e pelo Estatuto das Cidades, Lei 10.257, de 10 de julho de 2001. Segundo a CF (1988), "são direitos sociais a educação, a saúde, a alimentação, o trabalho, a moradia, o transporte, o lazer, a segurança, a previdência social, a proteção à maternidade e à infância, a assistência aos desamparados" (EC n²6/2000, EC $n^{0}$ 64/2010 e EC $n^{0}$ 90/2015), já o Estatuto das Cidades versa que "a política de desenvolvimento urbano, executada pelo poder público municipal, conforme diretrizes gerais fixadas em lei, tem por objetivo ordenar o pleno desenvolvimento das funções sociais da cidade e garantir o bemestar de seus habitantes" (Estatuto das Cidades, 2008, p.10). Porém, o que existe é a transformação desses direitos somente em discurso transformado, por vezes, em políticas públicas que, mesmo que contenham direcionamentos positivos para uma parcela da população, por ineficácia, não chegam a todos os lugares, marginalizando cidadãos do "direito à cidade", o direito de transformar a cidade e de (re)produzir o espaço sem as amarras condicionantes do sistema capitalista e dos meios de produção.

A industrialização advinda da construção da UHE Belo Monte é indutora de fatores e variáveis subsequentes, como a valorização do solo e processos de especulação imobiliária, que priorizam o valor de troca, transformando o espaço em mais-valia, intervindo "a tal ponto sobre o uso e o valor de uso que quase suprime este último" (Lefebvre, 2001, p. 20). A reflexão sobre as representações produzidas auxiliar a entender como a sociedade é 
influenciada e age a partir de determinados, sendo "nas cidades e nos lugares, mais especificamente, que os direitos, sob a forma de leis, aparecem de forma palpável e contraditória, decodificando-se em normas e posturas que regem a vida urbana" (Piñon de Oliveira, 2012, p. 177).

No caso Altamira, um processo de financeirização e um conjunto de transformações que atentaram contra as condições de vida levaram à constituição de movimentos sociais organizados e que, no caso especifico dos moradores da Lagoa do Independente I, se criasse uma significativa adesão às atividades realizadas pelo Movimento dos Atingidos por Barragens (MAB), construindo-se assim, uma reação, centrada na construção utópica do direito à cidade.

\section{Processos históricos e geográficos de Altamira e a favelização das planícies de inundação}

Tendo na sua gênese uma missão jesuíta do século XVIII criada com o propósito de evitar novas invasões estrangeiras no território português, a Vila Altamira começou seu desenvolvimento "enquanto núcleo", a partir da iniciativa do coronel Gaioso para promover uma economia de base escravista na foz do Rio Ambé" (Miranda Neto, 2016, p. 101). Paulatinamente devido a sua importância como principal ponto de escoamento da região do Xingu, é elevada à categoria de município em 06 de novembro de 1911 (Lei n¹234).

Com a expansão da produção gomífera e sua relevância dentro da lógica do mercado internacional, Altamira e outras cidades amazônicas, atraem fluxos migratórios, principalmente de nordestinos que se instalam nos seringais, portanto, na parte rural das cidades e vilas. Assim se firmava a relevância do núcleo como ponto de referência para o escoamento da borracha, ainda que o seu centro urbano se caracterizasse por uma baixa densidade populacional, que variava de acordo com as necessidades da atividade gomífera "compondo um arranjo urbano característico da Amazônia ribeirinha" (Miranda Neto, 2015, p. 2504). Esse quadro começou a mudar somente após o declínio da produção extrativista no final da década de 1960 e do início do regime militar (1964), que tem como um de seus 
desdobramentos, políticas de maior controle territorial, em que foram incentivadas novas ondas migratórias para a Amazônia.

Na região do Xingu, a partir da década de 1970, a materialidade de tais políticas se deu principalmente através das atividades do Programa Integrado de Colonização (PIC) e da construção da Transamazônica (BR-230), mudando a inserção regional da cidade de Altamira, que passa a ter uma maior concentração urbana, ao absorver população migrante e grande número de mão-de-obra excedente. Miranda Neto (2015) afirma ainda que,

\begin{abstract}
Sob iniciativa do Governo Militar, a cidade se torna o suporte logístico para as ações de colonização realizadas ao longo da rodovia Transamazônica (BR-230). A partir de então, se inicia um amplo deslocamento de migrantes para a área urbana, principalmente a partir da década de 1980 quando a política de fixação da população no campo demonstra sua fragilidade e tem, como efeito, um processo de migração intrarregional sem precedentes. Dessa forma, o papel da cidade de Altamira, antes um suporte logístico e funcional aos empreendimentos pioneiros, passa a ser de absorção da população migrante, cumprindo a função de estoque de mão-de-obra excedente. (Neto, p.2506, 2015).
\end{abstract}

Altamira tornou-se o principal polo econômico da região, porém a relevância dada ao setor produtivo não se refletiu em políticas que visassem o bem-estar dos cidadãos, o que, aliado à inexistência ou falta de execução de políticas públicas direcionadas ao planejamento urbano, fez com que a cidade fosse constituída de diversos espaços que fogem à normalidade, no que se refere a moradia: ocorrem aglomerados humanos irregulares, às margens dos igarapés (Ambé, Altamira e Panelas) e lagoas (como a Lagoa do Independente I), formados principalmente na década de 1980 e que aumentam de tamanho a cada nova onda migratória.

Estes aglomerados humanos subnormais ${ }^{5}$ já são denunciados em estudo realizado pela Secretaria de Planejamento do Estado do Pará, no ano de 1981, onde é apontada a ocorrência de ocupações em áreas desfavoráveis para a ocupação humana e o uso para moradia de áreas alagadas em determinados períodos do ano, que necessitam de infraestruturação urbana.

\footnotetext{
${ }^{5}$ Conjunto constituído por 51 ou mais unidades habitacionais, caracterizadas pela ausência de título de propriedade e pelo menos uma das características: irregularidade das vias de circulação e do tamanho e forma dos lotes e/ou carência de serviços públicos essenciais. (IBGE, 2010)
} 
Nas áreas marginais do Igarapé Altamira, a forma da ocupação se faz de maneira intensa, com habitações praticamente geminadas. Aí, o padrão construtivo decai, ocorrendo inclusive, o surgimento de palafitas, que devido à falta de instrumentos controladores do solo urbano e a inexistência de áreas apropriadas para a transferência da população aí residente, tende a se agravar. Essas áreas são carentes dos serviços de infraestrutura urbana e encontram-se com a maioria de suas vias em leito natural, necessitando com urgência desses serviços, uma vez que é significativo o seu contingente populacional (Neto apud Pará, 2016 p. 134).

Abunda um tipo de moradia proveniente da autoconstrução que é formada por troncos ou estacas adaptadas ao fluxo dos rios e lagoas, a palafita, em resultado da tradição ribeirinha na Amazônia e forma de resistência e sobrevivência, mas que, quando localizada em centros urbanos e sem a devida atenção e ação do Estado, se torna sinônimo de exclusão social e marginalidade, marcando a desigualdade social, pois que "não se trata das palafitas da tradição ribeirinha, cujas relações orgânicas entre o homem e a natureza tendiam a minimizar os riscos à saúde, mas de aglomerados em total degeneração das condições humanas" (Miranda Neto, p.138, 2016).

Porém, as políticas urbanas que poderiam frear essas ocupações e propiciar a esses cidadãos outros locais de moradias não foram executadas e a favelização das planícies de alagamento dos igarapés Ambé, Altamira e Panelas e da lagoa do Independente I continuaram. As palafitas foram sendo construídas, com acessos precários e sem nenhum tipo de esgotamento sanitário, ou acessibilidade à água potável (Figura 1).

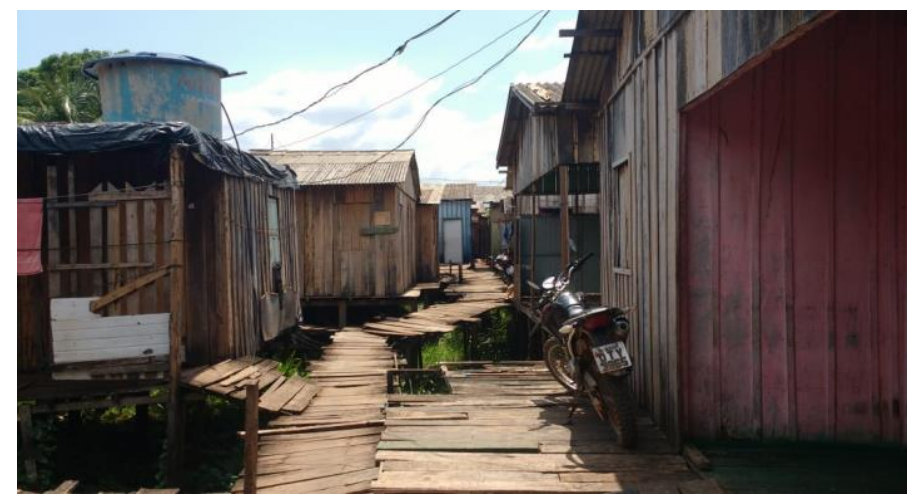

Figura 1 - Beco na Lagoa do Independente I.

Fonte: Recolhida pelos autores em 2018.

Paralelamente, era planejado ainda em meados de 1970, um conjunto de barragens no rio do Xingu, Kararaô, visando aumentar a capacidade de gerar energia e permitir o desenvolvimento de indústrias e cidades, principalmente nas regiões Sul e Sudeste. Porém, somente em 2010, após modificações substanciais no projeto inicial e com nova nomenclatura, o complexo hidrelétrico Belo Monte recebe a licença de instalação (LI), o que 
ocasiona nova pressão sobre a área urbana de Altamira que, embora não seja o município sede da construção da usina, é, sem dúvidas, o mais afetado, pois, além de ser o núcleo urbano que concentra as atividades econômicas e os serviços da região, possuía áreas do perímetro urbano abaixo da cota $100^{6}$, compondo os $51,9 \%$ da área do reservatório da usina (Rima, 2009).

A cidade, ainda com características ribeirinhas, confrontou-se com um panorama de exploração e uso do solo urbano, desta vez encabeçado pelos agentes imobiliários e a prática de ações mitigatórias e condicionantes exigidas para a construção do empreendimento hidrelétrico, o que causa uma profunda reestruturação de todo município.

A Norte Energia, responsável pelo empreendimento, para atender as condicionantes do Plano Básico Ambiental da UHE Belo Monte (PBA, 2011), no que se refere à habitação, construiu cinco loteamentos urbanos, os Reassentamentos Urbanos Coletivos (RUC's) de Jatobá, São Joaquim, Casa Nova, Água Azul e Laranjeiras, para onde foram remanejados os moradores que residiam nas planícies de alagamento dos igarapés Ambé, Altamira e Panelas. Posteriormente, pressionada por movimentos populares, como associações indígenas, de pescadores e ribeirinhos, pela Fundação Nacional do Índio (FUNAI) e o Ministério da Pesca, a empresa adquiriu nova área próxima ao Rio Xingu, para reassentar famílias de indígenas citadinos e pescadores, o Reassentamento Urbano Coletivo Ruc Pedral, conforme informa o Dossiê Belo Monte (ISA, p. 35, 2015), obra que se encontra-se em atraso de entrega e que prevê mais cerca de 600 casas.

No mapa a seguir (figura 2), observa-se para onde foram realocadas as famílias que optaram por receber como compensação a "casa" em um dos reassentamentos, usando-se critério de proximidade, de acordo com o que consta no PBA de Belo Monte, importando ressaltar que essa norma de proximidade não foi totalmente respeitada, já que há relatos de separação de famílias e amigos de décadas (Huffpost Brasil, 2019).

\footnotetext{
${ }^{6}$ A cota 100 estipulada pelo Estudo de Impacto Ambiental (EIA) de Belo Monte concluído em 2009, refere-se à altitude que o rio Xingu irá atingir com a construção da usina. Nele, as áreas urbanas situadas abaixo da cota altimétrica de 100 metros foram denominadas Áreas Diretamente Afetadas (ADA Urbana) e os limites são baseados nas cheias históricas do Rio Xingu, que até então havia atingido 99,27 metros em 1980 (EIA, 2009).
} 


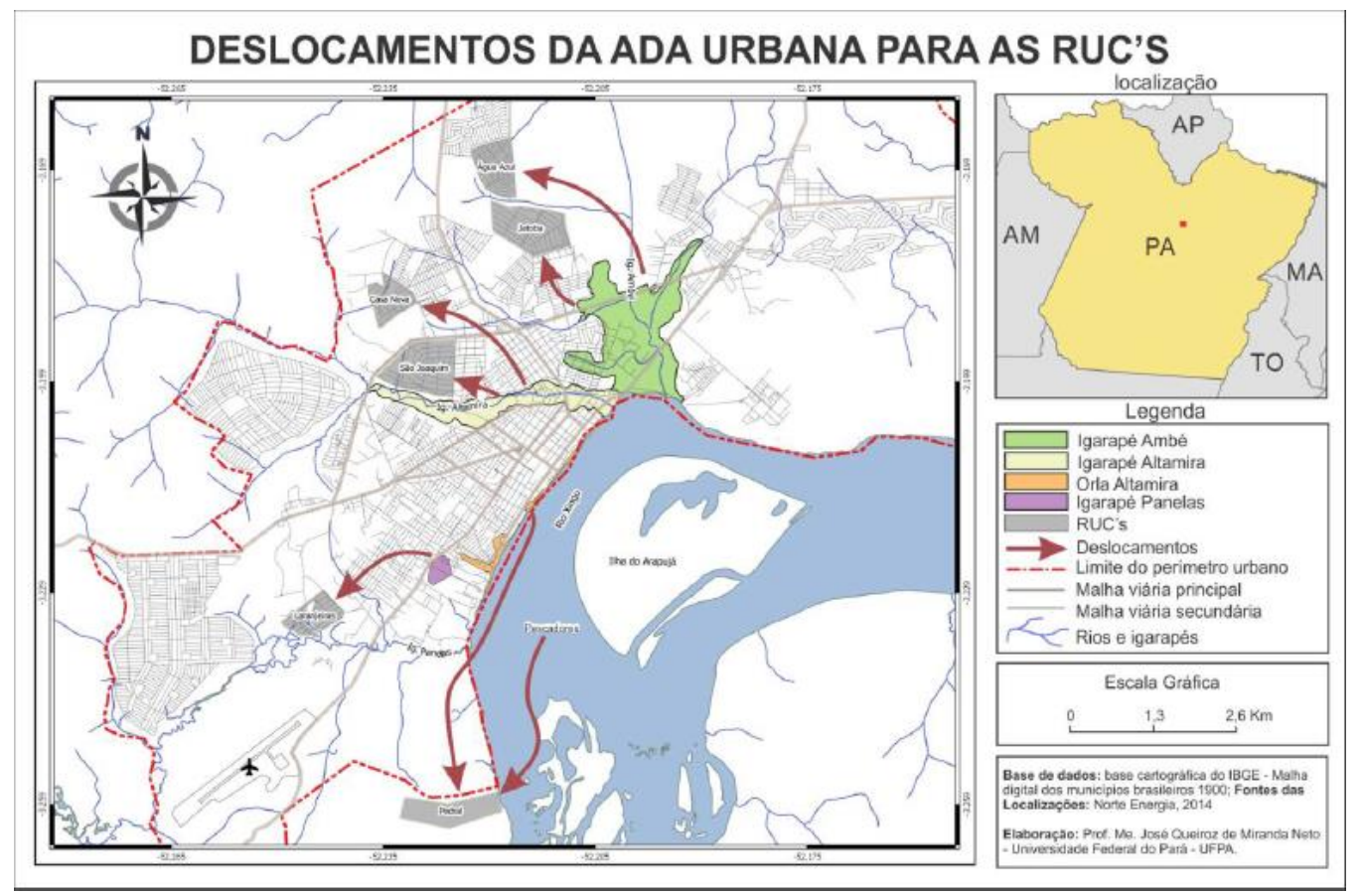

Figura 2 - Mapa de deslocamentos na Área Urbana.

Fonte: Neto (2016)

\section{A Lagoa do Independente I - Desestruturação social e a luta dos moradores pelo reconhecimento como atingidos}

A área de Lagoa do Independente I, localizada no bairro Independente I, antes da construção do empreendimento hidrelétrico, apresentava inundações e alagamentos, inerentes ao inverno amazônico. É uma área cujas cotas altimétricas são menores que as presentes no entorno do terreno (Miranda Neto, Alvarez, 2017), mas que estão acima da cota 100 (EIA, 2009) e, portanto, excluída a área da Lagoa das ações mitigatórias do projeto (Figura 3). 


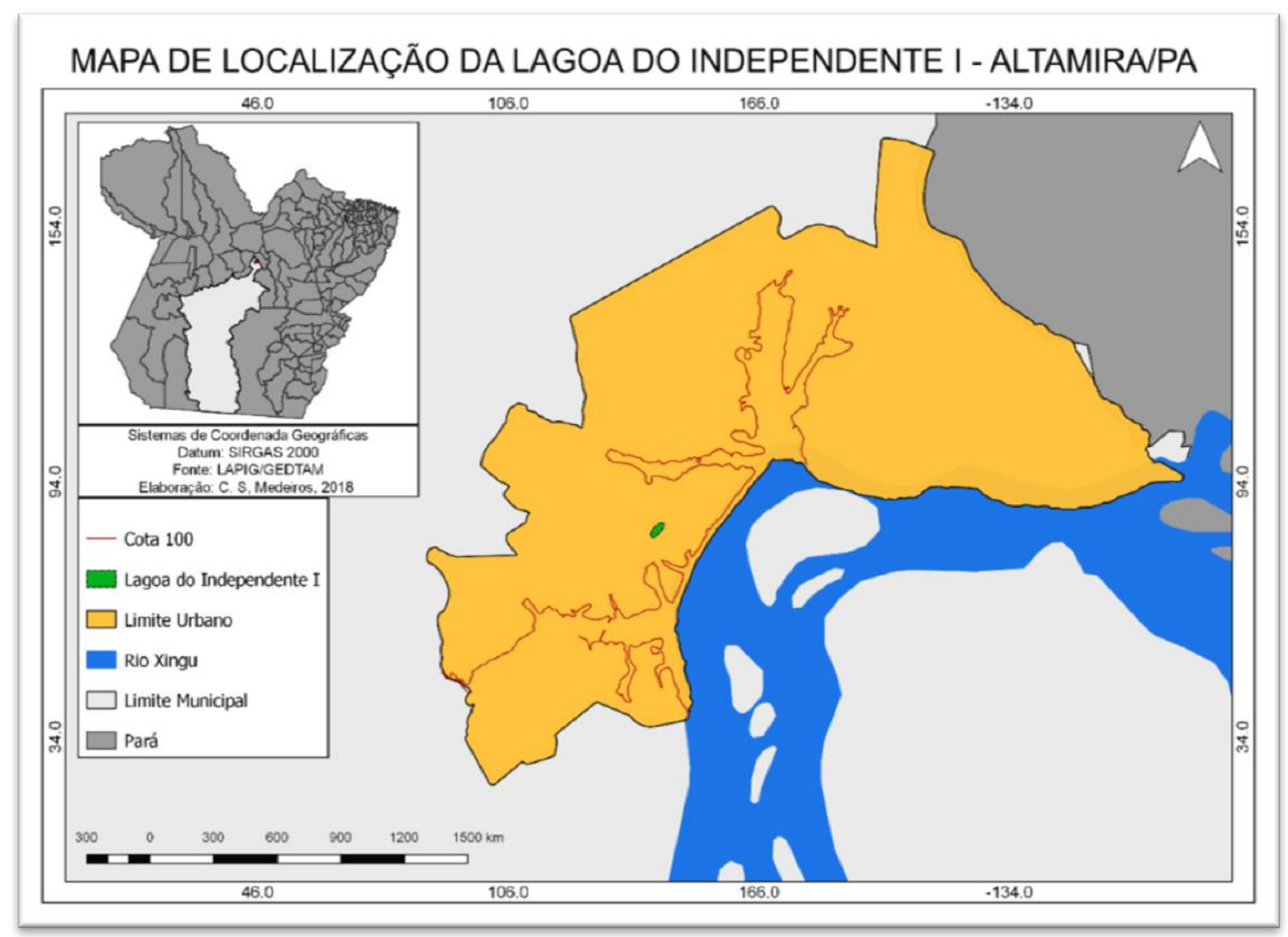

Figura 3 - Mapa de localização da Lagoa do Independente I.

Fonte: Medeiros (2018)

A área no entorno de uma lagoa sazonal foi inicialmente ocupada irregularmente por um pequeno número de famílias, de acordo com Semas, 2016.

A ocupação da "Lagoa" no Jardim Independente I, no município de Altamira ocorreu, na década de 1990, e na época, aproximadamente 40 a 50 famílias, moravam em torno de uma lagoa sazonal, na zona urbana do município de Altamira, que antes, até então, ao receber, em seu leito, as precipitações pluviométricas, seguia seu curso hidrológico natural e, secava, pelo processo de evaporação, segundo os relatos de representantes, durante a visita técnica desta equipe, na comunidade local, a "Lagoa" enchia, durante o regime de chuva e, secava, visto que era utilizada até como campo de futebol (RT $\mathrm{N}^{\circ}$ 7100/GEINFRA/2016, Semas, 2016).

Trata-se, como antes se referiu, de um espaço urbano sem infraestrutura adequada para moradia, com edificações de alvenaria em suas extremidades e de madeira em seu interior, onde a inexistência de políticas públicas permitiu que o processo de ocupação se intensificasse, ainda que de forma lenta e gradual, o que só veio a mudar a partir de 2010, como resultante das implicações desencadeadas pela licença de instalação da usina, como pode ser observado quando se comparam entre as imagens de satélite colhidas na área da Lagoa do Independente I nos anos de 2005, 2014 e 2017 figuras 4, 5 e 6). 


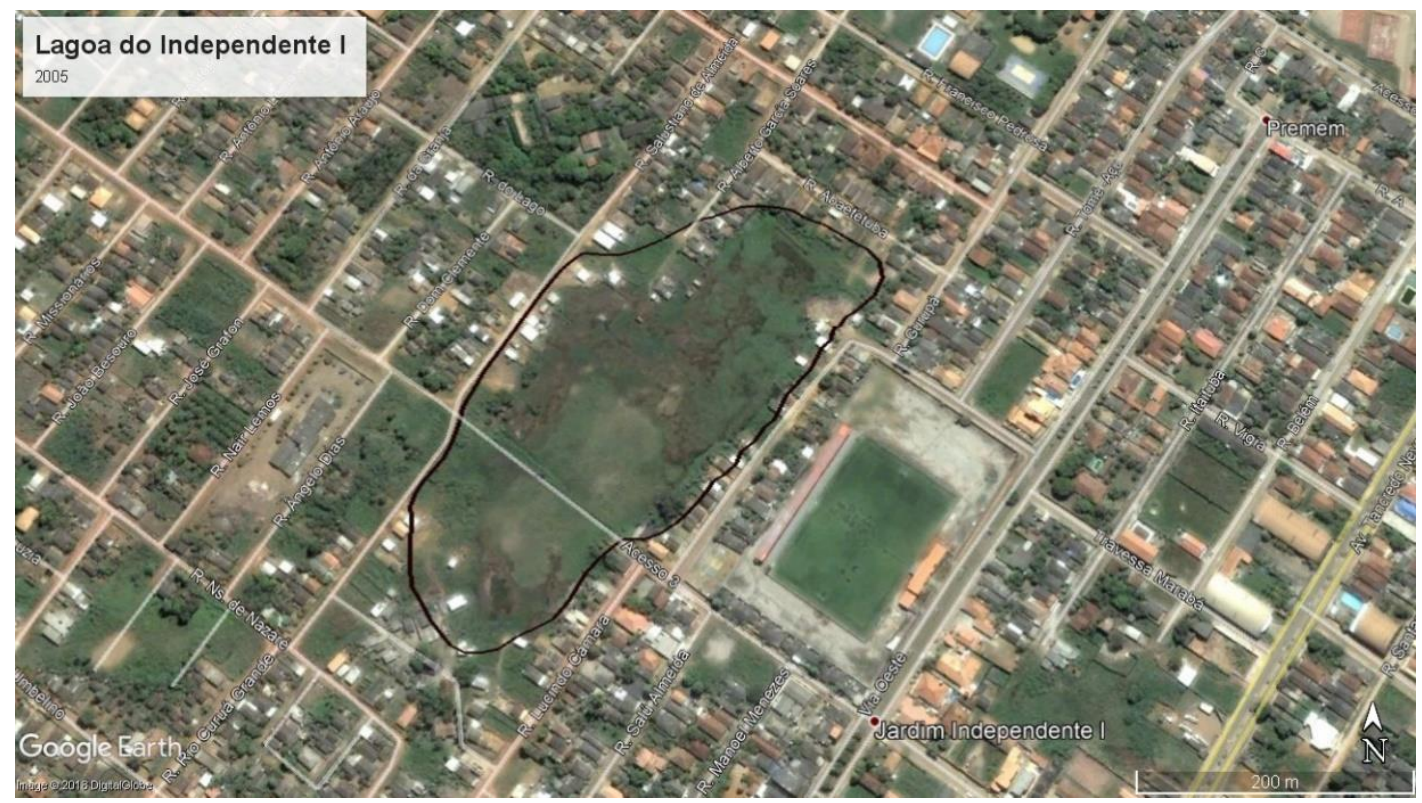

Figura 4 - Imagem de satélite da área da Lagoa do Independente I no ano de 2005. Fonte: Adaptado de Google Earth.

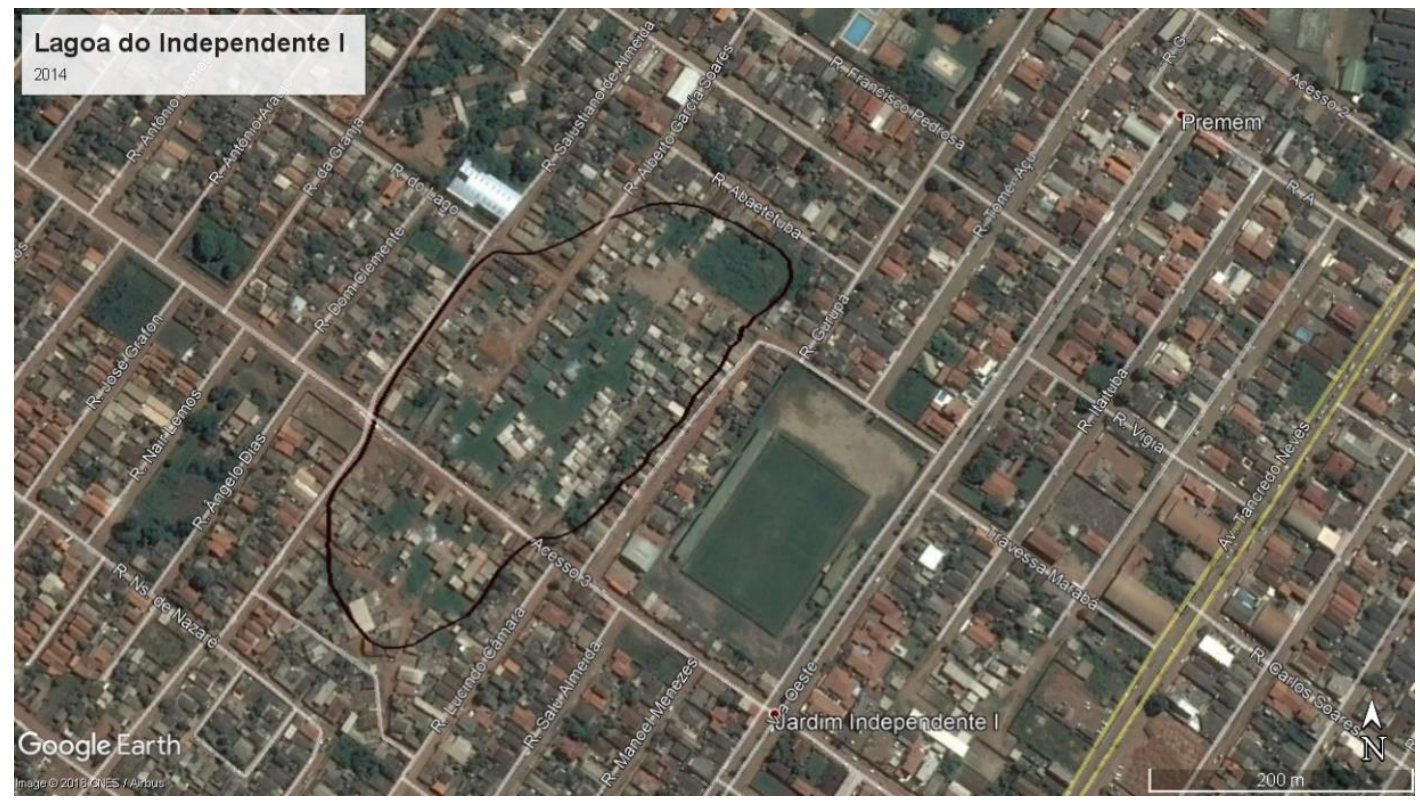

Figura 05 - Imagem de satélite da área da Lagoa do Independente I no ano de 2014. Fonte: Adaptado de Google Earth. 


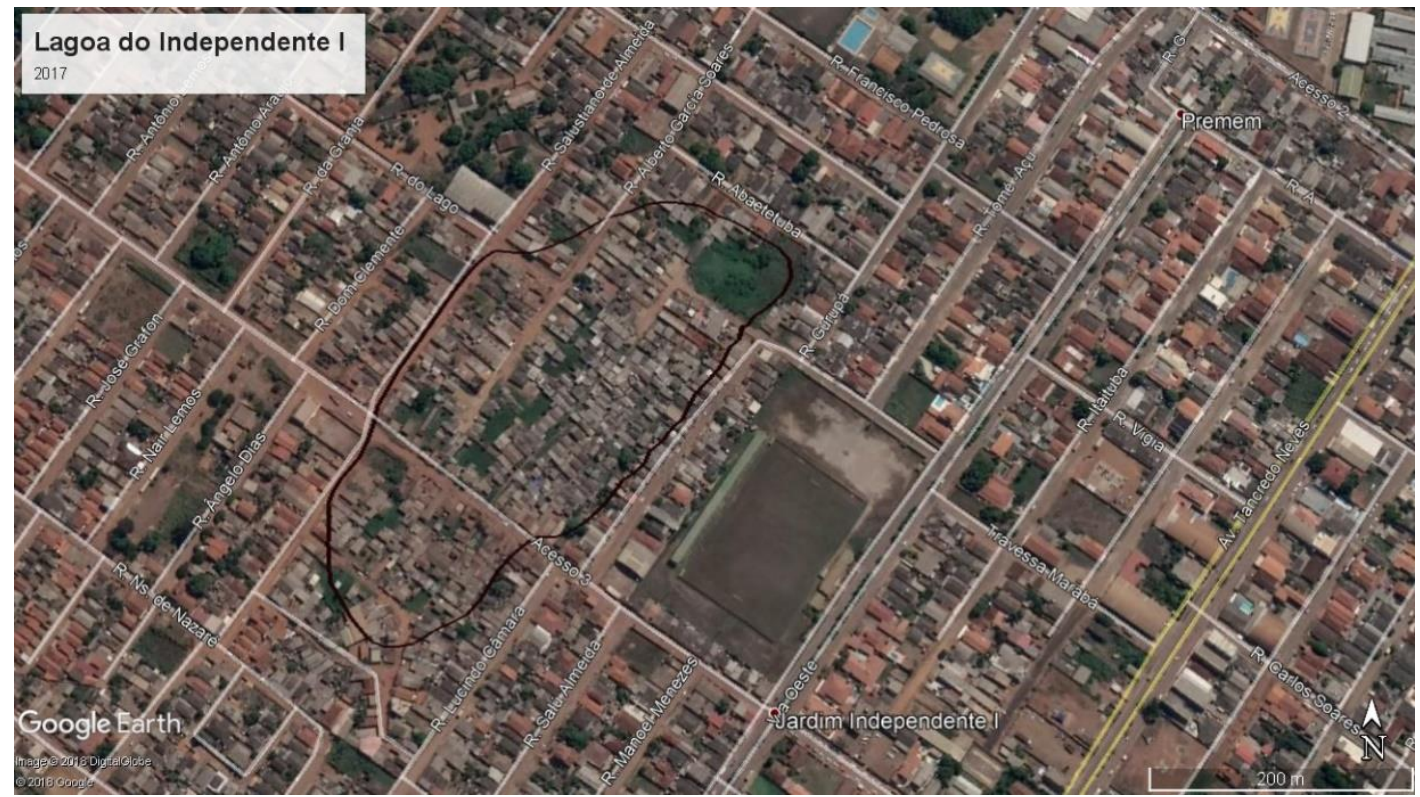

Figura 6 - Imagem de satélite da área da Lagoa do Independente I no ano de 2017. Fonte: Adaptado de Google Earth.

Verifica-se que entre os anos de 1980 e 2005, portanto em mais de vinte anos, ainda não se tem uma ocupação densa, não havendo grandes mudanças da paisagem do interior da lagoa, que apresenta vegetação aparente e edificações somente em suas margens.

Com o passar do tempo o entorno dessa área foi sendo ocupada pela urbanização e a drenagem natural aos poucos vai sendo aterrada. A ponto de praticamente deixar de existir. Para remediar esse problema o poder público não promoveu a implantação de obras de drenagem, e por isso se conclui que a ausência de drenagem representa a causa de maior alamento na área. É importante observar que [...] o processo de urbanização do entorno do Lago é intensificado a partir do momento em que é deliberada a construção da UHE Belo Monte com forte incremento no processo migratório (SEMAS, 2016, p. 2).

Entre os anos de 2000 e 2010 (uma década), o crescimento da população do município de Altamira registou um aumento de 21.720 habitantes e de 2010 a 2018 um aumento de 14.120 pessoas, números, só por si, não explicam o afluxo populacional que ocorreu no interior da Lagoa do Independente I, mas auxiliam no entendimento que os novos moradores da área, foram direcionados/empurrados pelo novo panorama de uso e exploração do solo e por fatores econômicos para fixarem sua residência ali, num local sem condições mínimas para a fixação humana. 
Tabela 1 - Evolução da população do município de Altamira entre 2000 e 2018.

\begin{tabular}{l|llllll}
\hline Ano & 2000 & $2010 *$ & 2012 & 2014 & 2016 & 2018 \\
População & 77.355 & 99.075 & 102.343 & 106.768 & 109.938 & 113.195
\end{tabular}

Fonte: IBGE (Censo demográfico 2010*), Anuário Estatístico FAPESPA $(2015,2019)$.

Com a justificativa de que a Lagoa do Independente I se encontrava acima da cota 100 , os estudos avaliativos realizados para a instalação e operação de Belo Monte não detectaram impactos socioambientais diretos gerados pela implantação da usina, considerando-se assim que não seriam necessárias ações indenizatórias (requalificação do espaço da lagoa e remanejamento para seus moradores), deixando de se considerar os efeitos da valorização do solo e especulação imobiliária associados e a grandes obras, embora tal constasse no Relatório de Impacto Ambiental (EIA/RIMA, 2009).

Introduziu-se no tecido da malha urbana, neste momento, novos loteamentos urbanizados em um "total de 22 mil lotes conduzidos por empresas incorporadoras" (Neto, 2016, p. 206), o que limitou e freou a ocupação irregular de novos pontos. Sem estar sob a tutela do empreendedor e com a inexistência de qualquer tipo de intervenção pelo poder público, a Lagoa tornou-se o único espaço urbano com proximidade ao centro da cidade propício à instalação de novas construções irregulares, um refúgio do alto valor dos aluguéis e da nova dinâmica do mercado na região, caracterizado pela exclusão. É importante ressaltar que acontece um conflito de interesses entre o empreendedor e o poder público municipal na área da Lagoa, um delegando ao outro os honorários necessários para a reestruturação socioambiental do local, o que gera um entrave de ações e impulsiona o afluxo populacional.

\footnotetext{
"a desestruturação social é consequência da ineficiente ação estatal para a complementação das suas necessidades. Bem como, a expansão do capital no território gera a perca da funcionalidade e autonomia do setor público local e o conjunto desses fatores, agentes e objetivos resulta em conflitos ideológicos de busca no e pelo poder territorial" (Moreira, 2013).
}

Buscando compreender as variáveis decorrentes do empreendimento hidrelétrico e da ineficiente ação do Estado que impulsionaram o adensamento populacional do interior da Lagoa, foram realizadas 68 entrevistas com moradores residentes em palafitas ou outras 
soluções de autoconstrução, cujo total, de acordo com o documento PT-23/2018COHID/CGTEF/DILIC do Ministério do Meio Ambiente (MMA) e do Instituto do Meio Ambiente e dos Recusrsos Naturais Renováveis (IBAMA) de 2018, é formado por 496 famílias, o que reflete uma análise amostral de 13,7\%. Cabe ressaltar que o número de entrevistas não foi maior devido ao alto índice de casas abandonadas ou fechadas durante as visitas. Estas, realizadas preferencialmente no período diurno, em função da dificuldade de deslocamento dos pesquisadores nas estruturas usadas pelos moradores, como vias de acesso (ver figura 7), retrata as deficientes condições de acessibilidade.

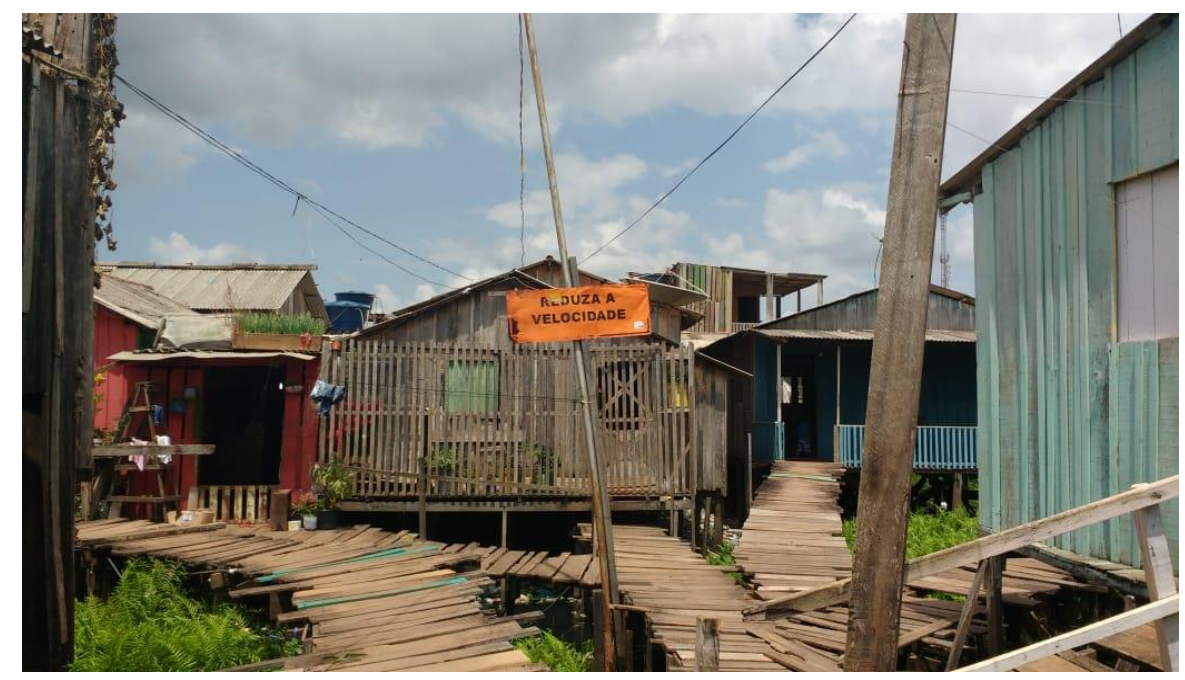

Figura 7 - Acesso ao interior da Lagoa do Independente I.

Fonte: Recolhida pelos autores em 2018.

O perfil dos moradores entrevistados revela que $66 \%$ são do sexo feminino e $34 \%$ do sexo masculino, divididos em $85 \%$ com a faixa etária entre os 20 e 59 anos, $9 \%$ com idade de 60 anos ou mais e $6 \%$ entre 18 e 19 anos. No que se refere a escolaridade, $41 \%$ cursaram ou concluíram o ensino médio, $25 \%$ cursaram ou concluíram o ensino fundamental maior (compreende do 60 ao 9o ano do ensino básico), 22\% cursaram ou concluíram o ensino fundamental menor (séries iniciais) e 12\% não estudaram. Ainda sobre a escolaridade, destaca-se que os moradores entrevistados informaram não ter estudado ou concluído o ensino superior, o que demonstra que $59 \%$ dos respondentes tem baixo ou nenhum acesso à educação.

Quando perguntados sobre seu local de nascimento, $56 \%$ responderam que são natos do estado do Pará, destes apenas $31,5 \%$ são oriundos de Altamira, os outros $44 \%$ do total de 
famílias pesquisadas são procedentes de outros estados (figura 8). Cataloga-se esse dado para confirmar a ideia de que os habitantes da área, em percentual elevado, são originários dos fluxos migratórios que ocorrem em função do evento Belo Monte e que ocorreram ao longo do processo histórico formativo do município de Altamira, cabendo as áreas impróprias para moradia o lócus de acomodação da mão-de-obra excedente e vulnerável.

\section{Naturalidade dos entrevistados}

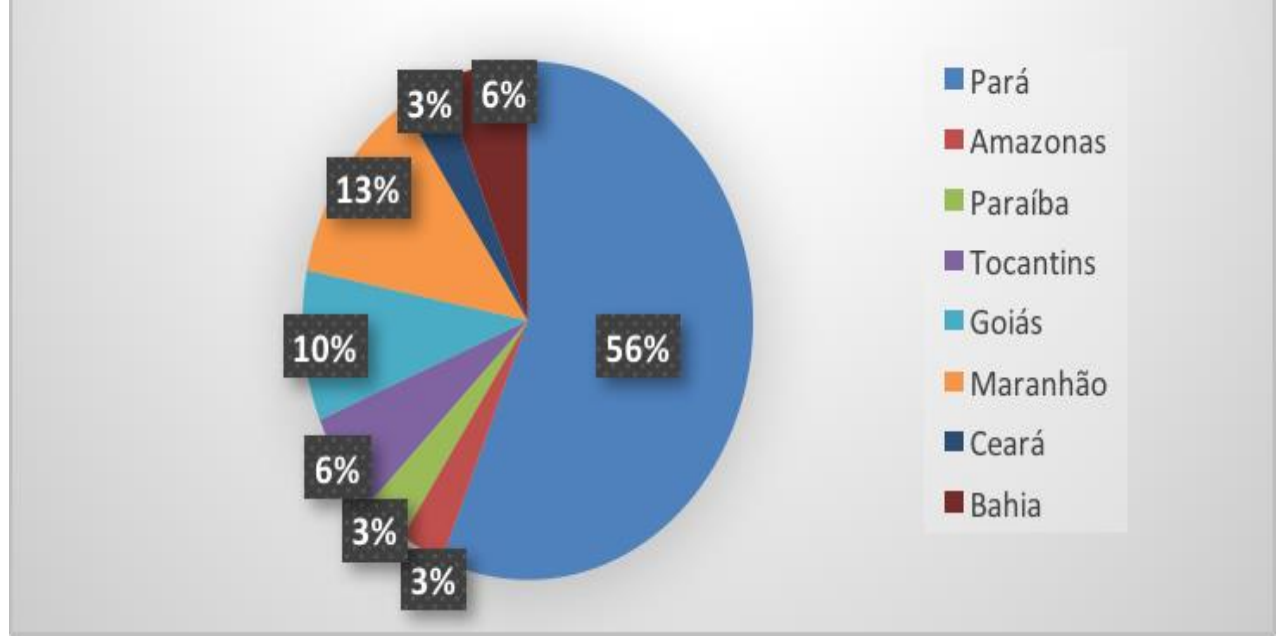

Figura 8 - Gráfico de naturalidade dos entrevistados.

Fonte: Elaboração própria com dados recolhidos em 2018.

53\% responderam que tem rendimentos até 1 salário mínimo ( $R \$ 954,00$ - ano base 2018), 35\% disseram receber 1 salário mínimo, 6\% afirmaram não ter nenhuma renda e sobreviver de doações, $3 \%$ informou ter renda superior a $\mathrm{R} \$ 954,00$ e outros $3 \%$ não souberam informar o valor da renda mensal. Já em relação à composição destes grupos familiares, de acordo com as respostas obtidas, aponta-se que $28 \%$ moram com 3 a 4 pessoas em uma mesma casa, em $25 \%$ dos casos a residência é composta por 5 a 6 indivíduos, outros $25 \%$ por residências com 1 a 2, 19\% com 7 a 8 pessoas e 3\% com 9 a 10 habitantes. Portanto, é possível perceber a insegurança econômica em que vivem essas famílias quando comparado a renda mensal dos núcleos familiares com o número de residentes por imóvel, pois, na maioria deles, 3 a 4 pessoas recebem no máximo 1 salário mínimo para subsidiar as despesas com a manutenção da vida. 
A pesquisa demonstrou ainda que o grupo entrevistado, em sua maioria, reside na lagoa entre 5 e 6 anos, 37\% do total, outros $25 \%$ habitam o espaço entre 3 e 4 anos, $13 \%$ estão no local entre 7 e 8 anos, outros 13\% moram há 9 ou 10 anos, 9\% entre 1 e 2 anos e 3\% afirmaram estar residindo no local há menos de 1 ano. Tais números evidenciam que o pico de chegada desses moradores ocorre ao mesmo tempo em que o fluxo migratório decorrente de Belo Monte está em seu auge, entre os anos de 2012 e 2015.

\begin{abstract}
"Depois da chegada de Belo Monte eu vim morar aqui pela falta de outra opção de moradia, o custo de vida ficou alto e por causa disso, não tenho como morar em outro local. Para mim, morar aqui é triste, o local tem muito mau cheiro e há risco constante das crianças caírem na Lagoa, já teve até morte de criança. Porque o sonho de qualquer ser humano é ter um lugar para chamar de seu, aqui é meu, mas não posso dizer que tenho um lugar no chão, onde eu possa fazer um pequeno plantio" (E. L. C., moradora da Lagoa, 2018).
\end{abstract}

No fragmento acima, a voz da moradora, evidencia a profícua ligação entre o adensamento populacional da Lagoa e a implantação e a construção da usina, como também deixa explícito as condições de desumanidade e risco de morte em que vivem as pessoas que ali habitam. Sua fala explana ainda um anseio de morar em terra firme, o direito a usufruir da terra urbana, garantido em leis como a Constituição Federal e no Estatuto das Cidades.

Em relação às condições de suas moradias anteriores, 44\% responderam serem originários de loteamentos regulares (bairros do perímetro urbano de Altamira), percentual que é o mesmo para os moradores que afirmam que em sua casa anterior moravam de aluguel. Procedentes de outras cidades somam 19\%, outros $19 \%$ da zona rural, o que corrobora com a ideia de que além de atrair migrantes de outras cidades e regiões, a instalação de grandes eventos, como Belo Monte, também revela a inversão que Altamira passou ao longo de sua história, deixando de ser uma cidade com predominância de moradores na zonal rural para uma cidade com densidade populacional maior em seu núcleo urbano. Para além deste aspecto, 15\% disseram ser oriundos de ocupações irregulares, dado que instiga curiosidade, uma vez que as outras ocupações irregulares que havia na ADA receberam ações mitigatórias por parte do empreendedor. Dos entrevistados, 3\% afirmaram ainda se enquadrarem em outra precedência, originários de alojamento dos trabalhadores do CCBM (Consórcio Construtor Belo Monte).

Miranda Neto (2016), a esse respeito faz uma afirmativa coerente com a realidade destas famílias, que mesmo em melhor condição de habitabilidade, não deixam de ser segregados 
da cidade e de suas benfeitorias, tornando-se a Lagoa, espaço aberto para a construção de moradias, refúgio de resistência para aqueles que não tinham condições econômicas de usufruir de outro local de moradia na cidade.

Essa realidade escancara, mais uma vez, a face da desigualdade social na cidade, pois apesar de as residências possuírem melhores condições de habitabilidade, os rendimentos familiares e as suas condições de trabalho e emprego permanecem as mesmas. Ademais, os custos relacionados à moradia são ampliados por conta das faturas de energia, água, IPTU etc. que devem ser arcadas pelos moradores. Como um processo associado à reprodução da vida, resta então a decisão de se desfazer do imóvel do RUC, adquirir outro terreno (possivelmente em área irregular) e utilizar o valor restante para suprir, pelo menos por algum tempo, as despesas familiares (Neto, 2016, p. 187).

Quando perguntados sobre a proximidade e acesso aos serviços básicos que eles tinham na antiga casa e realizando um comparativo com o que eles possuem, foi possível montar o gráfico comparativo (figura 9), onde as colunas em azul representam o primeiro momento, a acessibilidade que o morador possuía na sua residência anterior, e as colunas em laranja a realidade vivenciada após a mudança para a área da lagoa. Compreende-se que das nove categorias elencadas, somente os serviços de saúde, comércio e educação possuem percentual relevante ao acesso dos mesmos, nos demais, embora a origem dos respondentes seja de locais variados, inclusive de outros municípios, a residência na área da lagoa dificulta ou nega o acesso a maioria dos serviços.

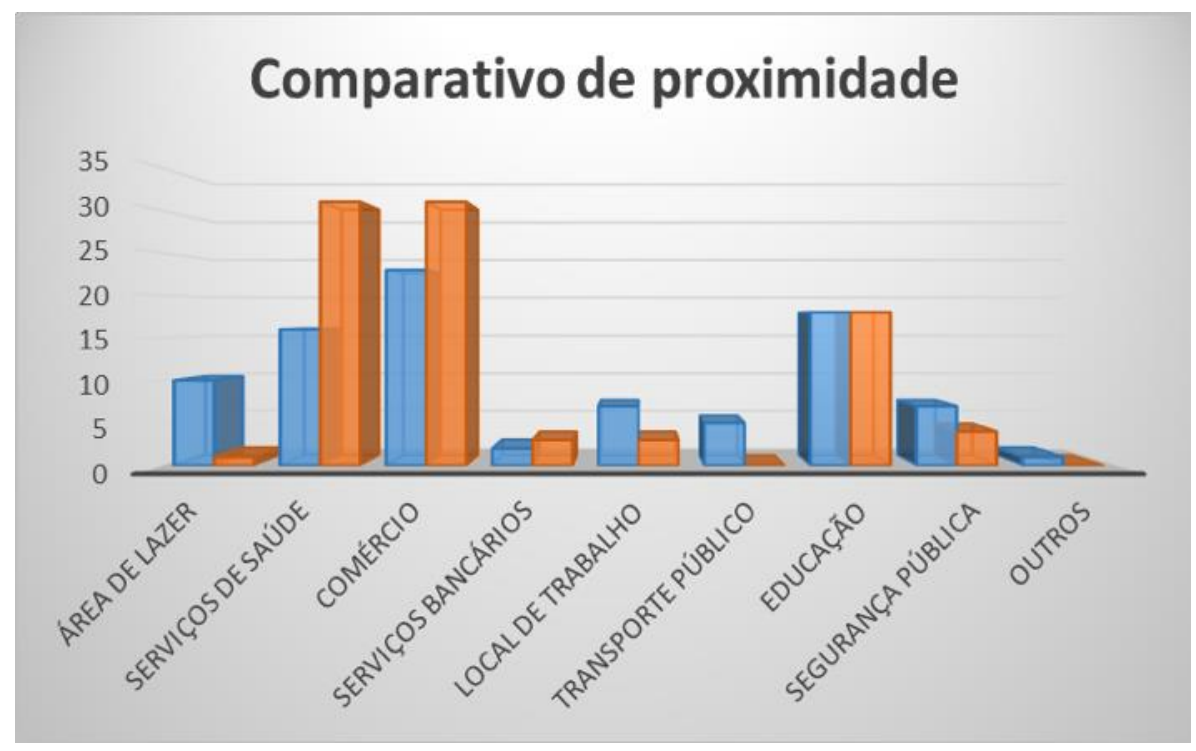

Figura 9 - Gráfico da condição de moradia anterior dos entrevistados. Fonte: Elaboração própria com dados recolhidos em 2018.

Compreende-se que das nove categorias elencadas, somente os serviços de saúde, comércio e educação possuem percentual relevante, nos demais, embora a origem dos respondentes 
seja variada, a residência na área da lagoa dificulta ou nega o acesso à maioria dos serviços. A afirmação da moradora N.S.P. esboça um quadro ainda mais preocupante, pois embora haja uma proximidade espacial com uma Unidade Básica de Saúde (UBS), ela compreende que não há um acesso ao serviço,

\footnotetext{
“É ruim morar na Lagoa porque aqui não tem estrutura de nada, não tem nem sequer serviço de saúde, nós somos estigmatizados, malvistos pela sociedade, de gangue, bandidos. E não é isso, somos como qualquer pessoa, com direito a ter saúde, boa estrutura, saneamento básico, ter uma vida digna. Nossos filhos têm que ter um lugar melhor para morar, não pegar tantas doenças, ter um posto de saúde próximo que atenda a gente" (N.S.P., moradora da Lagoa, 2018).
}

Durante as entrevistas, outros moradores reforçaram o que a cidadã N.S.P. relatou e dentre eles, um afirmou que "quando procurava o posto de saúde e falava que era morador da Lagoa, não ela atendido e por isso quando tem febre, fica vagando, até soar e a febre sair" (E.L.C., morador da Lagoa, 2018).

Perguntados sobre os motivos que os levaram a residir na área da Lagoa, a grande maioria relacionou sua ida com o aumento dos valores dos aluguéis que ocorreu em Altamira (figura 10). Ainda referente aos motivos da ida para a lagoa, os demais relatados são a falta de outra opção de moradia, a proximidade com o centro e outros, como a dificuldade para continuar morando na zona rural, o que reflete que mesmo com as ações que levaram a um processo de ruralização recente, o deslocamento rural-urbano continua a existir, "pois em função das diferentes formas de vinculação do trabalho ao capital uma parte importante das famílias é sujeita a condições de trabalho degradantes" (Miranda Neto, p.127, 2016). Tais fatores, aliados ao convite feito pela instalação da hidrelétrica, fizeram com que muitas pessoas se deslocassem para o centro urbano com maior importância econômica, dentre os municípios de influência, com a esperança de um emprego melhor. 


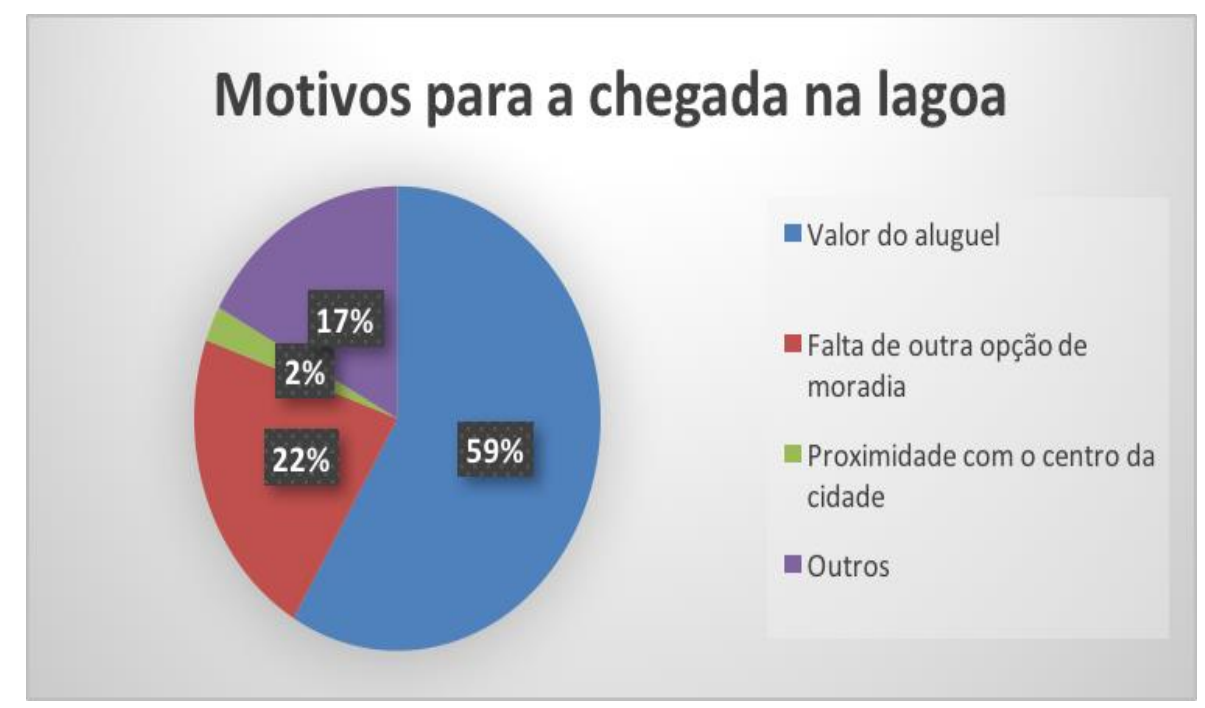

Figura 10 - Gráfico da condição de moradia anterior dos entrevistados.

Fonte: Elaboração própria com dados recolhidos em 2018.

Essa (re)produção socioespacial da Lagoa, embora aconteça em diferentes escalas e abrangendo diferentes realidades individuais, coloca os envolvidos em uma posição de vulnerabilidade que vai além da falta ou ineficiência de políticas públicas, como as ligadas ao saneamento básico, em que as entrevistas apontam que somente a água potável é utilizada, mesmo assim de forma precária, com traços explícitos de marginalização e exclusão social, uma vez que serviço público algum adentra no núcleo da área, "porque aqui não tem energia própria, não tem água própria, é tudo gato, quando as mangueiras rompem, a gente sai correndo para tentar remendar para não ficar sem água. Os fios de energia elétrica são um perigo, a qualquer momento pode pegar fogo em tudo" (V.M.S., moradora da lagoa, 2018).

Outra exterioridade vivenciada no cotidiano dos moradores é a presença de mau cheiro, provocado pelo acúmulo de lixo e o alagamento constante. Além disso, foi relatado na maioria dos casos, uma alta incidência de animais indesejados, como insetos, animais peçonhentos e vetores de doenças (mosquitos, baratas, ratos, aranhas e escorpiões, entre outros).

O avanço no espaço da Lagoa do acúmulo do lixo embaixo das casas, da incidência de insetos e do mau cheiro (Tabela 2), de acordo com a percepção dos moradores respondentes nos anos de 2000, 2005, 2014 e 2018 é muito claro. Em 2005, temos um povoamento ainda incipiente, o que muda muito claramente nos anos de 2014 e 2018, o 
que está intimamente ligado à elevada migração para a área, efeito decorrente da instalação da UHE Belo Monte.

Tabela 2 - Quadro temporal de qualidade ambiental

\begin{tabular}{|l|l|l|l|l|}
\hline & 2000 & 2005 & 2014 & 2018 \\
\hline Acúmulo de lixo & Não sabe & Inexistente & Alto & Alto \\
\hline Incidência de insetos & Não sabe & Baixo & Alta & Alta \\
\hline Mau cheiro & Não sabe & Baixo & Alta & Alta \\
\hline
\end{tabular}

Fonte: Elaboração própria com dados recolhidos em 2018.

Durante a pesquisa obteve-se informações contraditórias quanto ao número de famílias na área da Lagoa: um relatório produzido pelo Movimento dos Atingidos por Barragem (MAB), em agosto de 2017, apontava 688 famílias, entre moradores do interior e das bordas da lagoa; o levantamento feito pela Norte Energia, realizado a partir de cadastramento de 2018, seguindo recomendações do IBAMA, apurou um total de 968 famílias e 548 imóveis.

O documento RT-PR-001/2018 regista o cadastramento de 968 famílias e 548 imóveis na região da lagoa. Destes 548 imóveis levantados, 293 estão localizados sobre palafitas e 255 estão em "terra firme". Em relação ao número de famílias, dos 968 registos, 496 estão em moradias sobre as palafitas e 472 em moradias em "terra firme" (NORTE ENERGIA, RT-PR-001/2018).

O cadastramento feito pela Norte Energia que subsidiou os processos indenizatórios resulta da batalha realizada pelos moradores, AMBAJI (Associação dos Moradores do Jardim Independente I) e MAB, pelo alargamento geográfico do reconhecimento de atingidos pela UHE Belo Monte, depois que surgiram minadouros e alagamentos permanentes. Os moradores inicialmente reivindicaram que fosse realizada uma nova medição, já que os estudos até então colocavam a lagoa acima da cota 100, dado que foi confirmado por pesquisa realizada pela ANA (Agência Nacional de Águas) e que também apontava a urgência da intervenção do poder público e da Norte Energia, uma vez que a continuidade de moradias em tal condição de precariedade apresentava um risco real a saúde da população residente.

O parecer da ANA, diversas ações do Ministério Público e de outros órgãos alimentaram a esperança dos moradores e dos movimentos sociais envolvidos, até que, em março de 2018, 
ocorre o reconhecimento dos mesmos como atingidos por Belo Monte. Porém, ocorre um conflito entre a Norte Energia e a Prefeitura Municipal de Altamira (PMA) sobre a responsabilidade de cada uma sobre a área e seus residentes, o que gera um entrave na retirada das famílias e requalificação da lagoa, que persiste, até à assinatura de um acordo, celebrado em outubro de 2018. Decide-se então, que o empreendedor é o responsável por indenizar as famílias e a PMA pela recuperação da área, o que, contudo, não ocorreu até o presente momento (março de 2020), havendo apenas a registar, a retirada de algumas famílias que estavam com suas casas em condição de risco e que estão recebendo o aluguel social.

Desse modo, é possível afirmar a existência de relações conflituosas entre as ações que emergem por conta do projeto hidrelétrico e aquelas que se produzem na defesa dos interesses locais. Por essa visão, embora prevaleçam como dominantes os eventos articulados pelo Estado e de interesse do grande capital, não há mudanças que se processem sem as tensões características de qualquer projeto de grande magnitude. No caso da usina de Belo Monte, há várias iniciativas desencadeadas por agentes locais (movimentos sociais, agentes do poder público e entidades) que alteraram a execução de alguns projetos, ainda que tais ações não sejam suficientes para interromper a continuidade do mesmo (NETO, 2016, p.172).

Durante a pesquisa, quando questionados sobre as expectativas quanto às condições de vida e moradia após o reconhecimento como atingidos por Belo Monte, os moradores respondentes, em sua maioria, consideraram que a suas vidas mudarão positivamente, com a celebração deste acordo. Foi apontado por $34 \%$ dos entrevistados que existirá uma melhor condição de moradia, outros 32\% consideram que terão melhor acesso a serviços básicos, como atendimento de saúde e $26 \%$ acreditam que em Belo Monte haverá uma melhor qualidade de vida.

Importa considerar que este desfecho só foi possível devido ao movimento social: $100 \%$ dos entrevistados disseram que o MAB foi de fundamental importância na luta por tal conquista e que sem ele, nada aconteceria de substancial. Obtiveram, portanto, antes de mais, direitos básicos de cidadania. Mas também, segundo a utopia lefevbriana, um direito à cidade, na perspectiva de sujeitos que participaram na transformação da realidade e do espaço geográfico em que vivem, sendo certo que esse direito necessita ser constantemente lembrado e garantido, não interpretado apenas na aplicação de políticas públicas e sim, na própria condição de cidadão. 
Somente seis meses após o reconhecimento como atingidas por Belo Monte a Norte Energia concluiu a retirada de 496 famílias da Lagoa do Independente I.

\begin{abstract}
Pois há 472 famílias vivendo no entorno da lagoa, para as quais a Norte Energia não apresenta prazo para dar tratamento. Além disso, dessas famílias, a empresa só reconhece o direito de 102 à indenização, no entanto, há cerca de 150 famílias cujas casas estão danificadas, apresentando rachaduras, insurgência de água e retorno do esgoto (MAB, julho de 2019).
\end{abstract}

Por isso, a luta social continua. Pois enquanto as políticas públicas não concentrarem seus esforços na produção e reprodução da vida humana, os impulsos revolucionários não serão capazes de transformar a vida cotidiana, conquistando uma política do urbano que venha a fazer sentido para aqueles que ali residem, considerando o uso material, assim como a imaterialidade necessária.

\title{
5. Conclusão
}

O modelo de desenvolvimento adotado na Amazônia, tem-se baseado na inserção de grandes empreendimentos, em sua maioria oriundos de escolhas exógenas que não respeitam a lógica tradicional e, historicamente, produzem espaços de extrema pobreza, bolsões marginalizados. Foi o que se verificou na cidade de Altamira, nas planícies de alagamento dos igarapés Altamira, Ambé, Panelas e na área da Lagoa do Independente que foi replicado (e ampliado) com a implantação da usina hidrelétrica Belo Monte, o que confirma a hipótese inicial que apontava a intrínseca ligação entre o crescimento populacional da Lagoa do Independente I e as implicações espaciais decorrentes do empreendimento, com o novo panorama de exploração do solo a elevar o valor dos aluguéis e o custo de vida na cidade, principalmente de 2012 à 2015, anos de pico da obra, forçando muitas famílias a morar na Lagoa, em condições inadequadas. Tal situação, evidencia a necessidade de políticas socioambientais e econômicas que priorizem o cidadão e não a reprodução do capital pelo capital. Além disso, considera-se necessário nos estudos para empreendimentos, como a UHE Belo Monte, a participação e envolvimento da sociedade desde o início, no planejamento, acompanhamento e avaliação, sobremaneira no que tange as medidas compensatórias, num processo pautado pelo rigor e transparência. 
Verificou-se que o direito à cidade é limitado, mesmo se compreendido liminarmente como acesso a direitos básicos, já que alguns moradores foram impedidos de desfrutar o que a cidade oferece: acesso à saúde, segurança, educação, lazer, moradia, mas também a sua imaterialidade, os sentimentos, direito que é primordial para a reprodução humana. A cidadania deixa de existir e resta a sobrevivência e o movimento social como umas das únicas possibilidades de resistência e de conquistas que não viriam sem a luta social, como foi por exemplo o reconhecimento como atingido por Belo Monte, categoria que os coloca em um patamar de cidadãos com direitos reconhecidos.

A constante luta passa a ser a possibilidade da conquista da cidade e, consequentemente da cidadania, apropriação: contradição, que contraria a lógica de uso e troca imposta pela propriedade privada.

\section{Referências}

Agência Nacional das Águas. Parecer Técnico Conjunto no 1/2016/COREG/SGH, ANA, 2016.Disponível em: https://www.ana.gov.br/. Acesso em set. 2018.

Brasil. [Estatuto da Cidade] Estatuto da Cidade 2008. - 3. ed. - Brasília, DF: Senado Federal, Subsecretaria de Edições Técnicas, 2008.

Brasil. [Constituição da República Federativa do Brasil (1988)]. Constituiçao da República Federativa do Brasil de 1988. Brasília, DF: Presidência da República, 1988.

Carlos, A. F. A. A (Re)produção do espaço urbano. 1ed. São Paulo: Editora da Universidade de São Paulo, 2008.

Carlos, Ana Fani Alessandri. A prática espacial urbana como segregação e o "direito à cidade" como horizonte utópico (p. 95-110) in P. A. Vasconcelos; R. L Corrêa; S. M. Pintaudi (Org.). A cidade contemporânea: Segregação espacial. São Paulo. Ed. Contexto, 1a ed. 2016.

ELETROBRÁS. Estudo de impacto ambiental - EIA, Relatório de impacto ambiental da Usina Hidrelétrica de Belo Monte - RIMA Belo Monte. Brasília, 2009.

FAPESPA. Fundação de Amparo a Estudos e Pesquisas do Pará. Anuário Estatístico do Pará 2015-2018. Disponível em: http://www.fapespa.pa.gov.br/menu/148/. Acesso em fev. 2020.

Gomes, P. C. C. A dimensão ontológica do território no debate da cidadania: o exemplo canadense. Revista Território, Rio de Janeiro, n. 2, 1997, p.43-62.

GOOGLE EARTH. Fotos de satélite. Disponível em: https://mapas.google.com/. Acesso em nov. 2018.

Harvey, D. Cidades Rebeldes: do direito a cidade a revolução urbana / David Harvey; Traduçao Jeferson Camargo. - São Paulo, Martins Fontes, 2014.

Herrera, J. A; Moreira. R. P. Resistência e conflitos sociais na Amazônia Paraense - a luta contro o empreendimento hidrelétrico Belo Monte. Campo-Território: Revista de Geográfia Agrária. Vol. 8, n. 16, p. 130-151, ago. 2013.

Herrera, J. A.; Santana, N. C. Empreendimento hidrelétrico e famílias ribeirinhas na Amazônia: desterritorialização e resistência à construção da hidrelétrica Belo Monte, na Volta Grande do Xingu. Geousp Espaço e Tempo (Online), v. 20, n. 2, p. 250-266, mês. 2016. ISSN 2179-0892. 
Herrera, J.A; A estrangeirização de terras na Amazônia Legal Brasileira entre os anos 2003 e 2014. CampoTerritório: Revista de Geografia Agrária. Ed. Especial, p. 136-164, jun. 2016.

Huffpost Brasil. Belo Monte, a violação de direitos humanos dos ribeirinhos e a ameaça ao Xingu. 2019. Acesso em: https://www.huffpostbrasil.com/entry/belo-monte-altamira br 5d6efef4e4b09bbc9ef644fd/ Acesso em set. 2019.

IBGE. Instituto Brasileiro de Geografia e Estatística. Censo demográfico 2010: Aglomerados subnormais primeiros resultados. Rio de Janeiro, 2010. ISSN: 0104-3145. Disponível em https://biblioteca.ibge.gov.br/Acesso em set. 2018.

Instituto Socioambiental ISA. Dossiê Belo Monte - Não há condições para a licença de operação. Disponível em: https://www.socioambiental.org/pt-br/noticias-socioambientais/dossie-belo-monte-remocao-das-

familias-provoca-perda-do-modo-de-vida-ribeirinho/JUN, 2015. ISBN: 978-85-8226-026-5. Acesso em fev. 2020.

Lefebvre, H. O direito a cidade. Trad. Rubens Eduardo Frias do original: Le Droit à La Ville. 5aed. São Paulo, Centauro, 2001.

Ledtam - Laboratório de Estudos das Dinâmicas Territoriais na Amazônia. Questionários de trabalho de campo realizados na Lagoa do independente I, Altamira: Universidade Federal do Pará, 2017-2018.

MAB AMAZÔNIA. Parecer Técnico no 23/2018-COHID/CGTEF/DILIC, MMA, IBAMA, 2018. Disponível em: https://www.mabnacional.org.br/noticia/mab-pede-suspen-da-licen-opera-belo-monte/. Acesso em out. 2018.

Ministério do Planejamento. Belo Monte, antes e depois. Publicado em 30/08/2011. Disponível em: http://pac.gov.br/noticia/0132dfd8/. Acesso em nov. 2018.

Miranda Neto, J. Q.; Alvarez, W. P. Relatório Técnico sobre ocorrências de alagamento no bairro Independente I - Área da Lagoa. Universidade Federal do Pará. Altamira - PA, 2017.

Miranda Neto, J. Q. Os nexos de re-estruturação da cidade e da rede urbana: O papel da Usina Belo Monte nas transformações espaciais de Altamira/PA e em sua região de influência. Repositório Institucional Unesp, Presidente Prudente - SP, 2016. Disponível em: <http://hdl.handle.net/11449/147134>

Miranda Neto, J. Q. UHE Belo Monte e a reestruturação da cidade de Altamira-PA: Agentes, processos e redefinições espaciais. Anais do XI-ENANPEGE, p. 2502-2513. Disponível em www.enanpege.ggf.br/2015> ISSN: 2175-8875.

Norte Energia S.A. Plano Básico Ambiental da Usina Hidrelétrica de Belo Monte. 2011. Disponível em: https://www.norteenergiasa.com.br/pt-br/ri/relatorios-anuais/document-100668/. Acesso em nov. 2018.

Norte Energia S.A. Relatório Técnico RT-PR-001/2018, NESA, 2018. Disponível em: https://www.norteenergiasa.com.br/pt-br/ri/relatorios-anuais/document-100668/. Acesso em nov. 2018.

Piñon de Oliveira, M. Para compreender o “Leviatã Urbano” - A cidadania como nexo político-territorial ( $p$. 177-206) in A. F. Alessandri; M. L. Souza; M. E. B. Sposito (Org.) A produção do espaço urbano: agentes $e$ processos, escalas e desafios. São Paulo. Ed. Contexto, 1a ed. 2012.

Santos, M. A Natureza do Espaço: Técnica e Tempo, Razão e Emoção. São Paulo: Ed. Edusp, 4ạ ed. 2009.

Santos, M. O Espaço do Cidadão. São Paulo: Ed. Edusp,7ạ ed. 2007.

Santos, M. Por uma Geografia Nova. São Paulo: Husitec, Edusp, 1978. 